\title{
Environmental determinants of diatom assemblages along a North African wadi, the Kebir-East, North-East Algeria
}

\author{
Nadjla CHAÏB, Ahmed H. ALFARHAN ${ }^{1)}$, Khaled A.S. AL-RASHEID ${ }^{1)}$ and Boudjéma SAMRAOUI ${ }^{1,2) *}$ \\ Department of Biology, University 20 August 1955, Skikda, Algeria \\ ${ }^{1)}$ Center of Excellence for Research in Biodiversity, King Saud University, Riyadh, Saudi Arabia \\ ${ }^{2}$ Laboratoire de Recherche des Zones Humides, Department of Biology, University of Guelma, Guelma, Algeria \\ *e-mail corresponding author: bsamraoui@yahoo.fr
}

\begin{abstract}
A total of 322 benthic diatoms with the majority being cosmopolitan species was recorded during a survey of the catchment area of the Kebir-East wadi, northeast Algeria. The spatial distribution patterns of diatom communities in relation to environmental gradients were examined using Co-Inertia Analysis (CIA) for ascertaining the interdependence between physico-chemical descriptors and diatom assemblages in 182 samples, collected over a period of 3 years, across 23 sampling stations. There was a significant covariance between the environmental data set and the benthic diatom data set with the CIA highlighting correlations between environmental factors and diatom species. A clear longitudinal gradient was a main driver of diatom communities with upstream sites characterized by high dissolved oxygen concentrations and downstream sites characterized by high organic load and nutrient enrichment of the water. A further factor influencing the shape of diatom assemblages was related to the conductivity, and the high values possibly reflected the close proximity of the sea to the downstream sites. An anthropogenic impact was also most evident in structuring diatom assemblages at sites close to Lake Oubeïra where agriculture was concentrated.
\end{abstract}

Key words: Diatoms, environmental gradients, intermittent streams, anthropogenic pressure, water quality, North Africa

\section{INTRODUCTION}

The River Continuum Concept (Vannote et al. 1980) has provided a stimulating theoretical framework for the research on ecological structural properties in running water systems (Hynes 1970; Junk 1999; Stanford \& Ward 1988). Spatial patterns of diatom species assemblages and environmental factors driving diatom species communities have been targeted by several studies (Biggs 1990; Pipp \& Rott 1994; Reavie \& Smol 1998; Rott et al. 1998; Pan et al. 1999, 2000; Potapova \& Charles 2003; Soininen 2002). These studies highlight the dominant role of chemical constituents and ion composition in the shaping of the structures of diatom communities (Johansson 1982; Soininen 2004). Knowledge of North African rivers or wadi is relatively poor and these water systems remain some of the least studied Mediterranean ecosystems. These limnological systems are subjected to harsh climatic conditions and, as they are located in a semi-arid region, are likely to experience marked physical and biological changes in the near future (Hulme et al. 2001). There is, however, a potent lack of knowledge about possible physical and biological changes that these hydrosystems are likely to experience in the light of climatic changes. Most studies of Algerian wadi have been confined to physico-chemical characteristics and macro-invertebrates (Lounaci et al. 2000; Belaidi et al. 2004) while studies on algae are rare (Baudrimont 1973).
Diatom species composition has been shown to be affected by anthropogenic pressures (Van Dam et al. 1994; Kelly \& Whitton 1998; Kovacs et al. 2006) and diatoms have been used routinely across the world to monitor water quality in rivers and streams (Schoeman 1979; Coste et al. 1991; Whitton \& Kelly 1995; Jüttner et al. 2003). The increasing demand for environmental impact assessment and the reliance on benthic diatoms as a tool to monitor the ecological quality of rivers have been highlighted by the European Water Framework Directive (European Commission 2000). Knowledge of how the interactions of geographical and environmental factors drive the distribution pattern of benthic diatom species is crucial for the development of water-quality assessment based on diatom monitoring. The aim of this study was two-fold: (1) to survey the diatom flora of the Kebir-East wadi, and (2) to relate the distributional patterns of benthic diatom species assemblages to environmental variables.

\section{METHODS}

The Kebir-East wadi originates at an altitude of $1200 \mathrm{~m}$ in the Ghora Mountain, Numidia, close to the Algerian-Tunisian border (Samraoui \& de Bélair 1998). The climate of the Kebir-East basin, northeastern Algeria, is typically Mediterranean with a dry and hot summer and with rainfall occurring mostly during the winter months. The sites sampled on the Kebir-East wadi (Fig. 1) and its effluents (streams) have a wide range of con- 


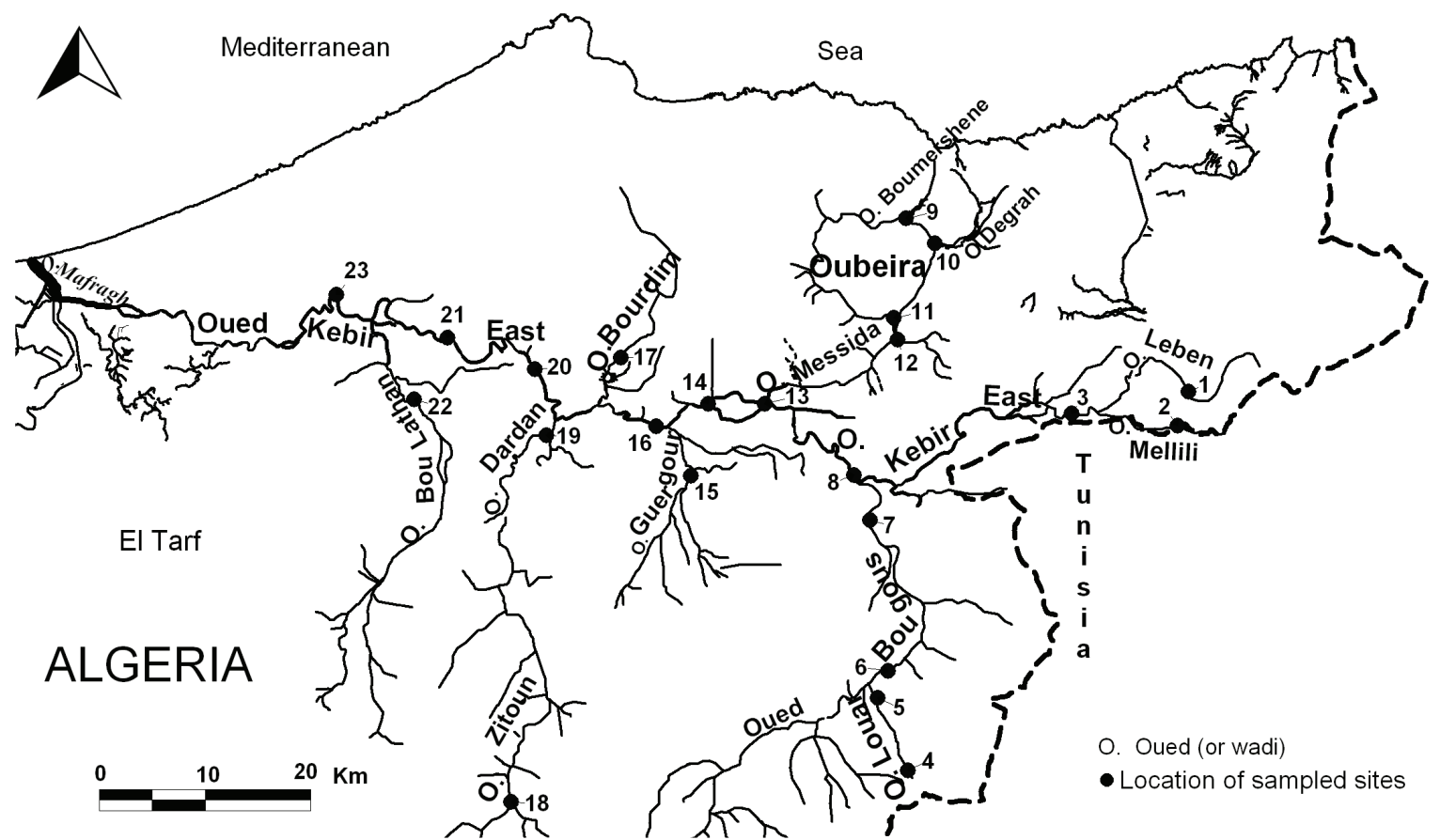

Fig. 1. Map of the Kebir-East hydrosystem in northeast Algeria with location of the sampled stations.

ductivity (0.1-3.0 mS cm$\left.~^{-1}\right)$, water depth, and hydroperiod (Zouini 1997). The list of sampled sites is provided in table 1 .

Tab. 1. List of the sampled sites.

\begin{tabular}{cl|cl}
\hline $\mathrm{N}^{\circ}$ & Name of Site & $\mathrm{N}^{\circ}$ & Name of Site \\
\hline 1 & Leben & 13 & Messida amont \\
2 & Mellili & 14 & Kebir at Aïn Khiar \\
3 & Kebir at R'Mel Souk & 15 & Guergour \\
4 & Louar amont & 16 & Kebir at Guergour \\
5 & Louar aval & 17 & Bourdim \\
6 & Bougous amont & 18 & Zitoun \\
7 & Bougous aval & 19 & Dardan \\
8 & Kebir at Aïn Assel & 20 & Kebir at Anènes \\
9 & Oubeïra 3 & 21 & Kebir at Righia \\
10 & Oubeïra 2 & 22 & Boulathan \\
11 & Oubeïra 1 & 23 & Kebir at Sebaa \\
12 & Messida aval & & \\
\hline
\end{tabular}

Over a period of 3 years (spring 2005 to winter 2008), a total of 174 samples were collected along the main course of the Kebir-East wadi and its 10 principal tributaries (Tab. 1) in northeastern Algeria (Fig. 1). No sampling took place in the summer of 2006. Sampling sites were selected on the basis of land-use information with the aim of sampling across a broad gradient of altitude (from $8 \mathrm{~m}$ to $650 \mathrm{~m}$ a.s.1.) and pollution levels (from near-pristine to heavily urbanized areas).

Samples of diatoms were collected according to a standardized method (NFT90-354) (AFNOR 2000), from five randomly chosen stones representing a total surface area of $1 \mathrm{~m}^{2}$. The stones were scraped with a toothbrush and the pooled material was kept in $500 \mathrm{~mL}$ dark bottles containing $5 \%$ formaldehyde.
Diatom species were identified at $1000 \times$ magnification using Zeiss light microscope with 400 valves per slide according to Krammer \& Lange-Bertalot (19861991), by examining permanent slides of cleaned diatom frustules, digested in boiling $\mathrm{H}_{2} \mathrm{O}_{2}(30 \%)$ and $\mathrm{HCl}$ $(35 \%)$ and mounted in a high refractive index medium (Canada Balsam, RI $=1.55$ ). Species and genera were identified according to Süsswasserflora von Mitteleuropa (Krammer \& Lange-Bertalot 1985-1991) in addition to some complementary works (Patrick \& Reimer 1966, 1975; Germain 1981; Hartley et al. 1996; Kelly 2000). Simultaneous with the collection of diatoms, physico-chemical data were collected. From the threeyears collection period, average values were calculated for each environmental variable. All physico-chemical parameters were recorded on the sampling date from 1.5 L samples collected from a free flowing area near the middle of the stream. The samples were stored at $4{ }^{\circ} \mathrm{C}$ and then analyzed within 48 hours, according to standardized protocols (AFNOR 2000).

The ecological determinants of diatom assemblages along the Kebir-East were subjected to Co-Inertia Analysis (CIA), a two-table ordination method similar to Canonical Correlation Analysis (CCA), using the ADE-4 package (Thioulouse et al. 2004). This multivariate analysis tool (Dolédec \& Chessel 1994) has been used to ordinate samples by researching a co-structure between physico-chemical variables and diatom species. The co-structure in CIA was determined by the maximization of the covariance, instead of correlation as in CCA, between the two new sets of projected coordinates. The significance of the resulting correlation $(R$ value) between the two sets of coordinates resulting 


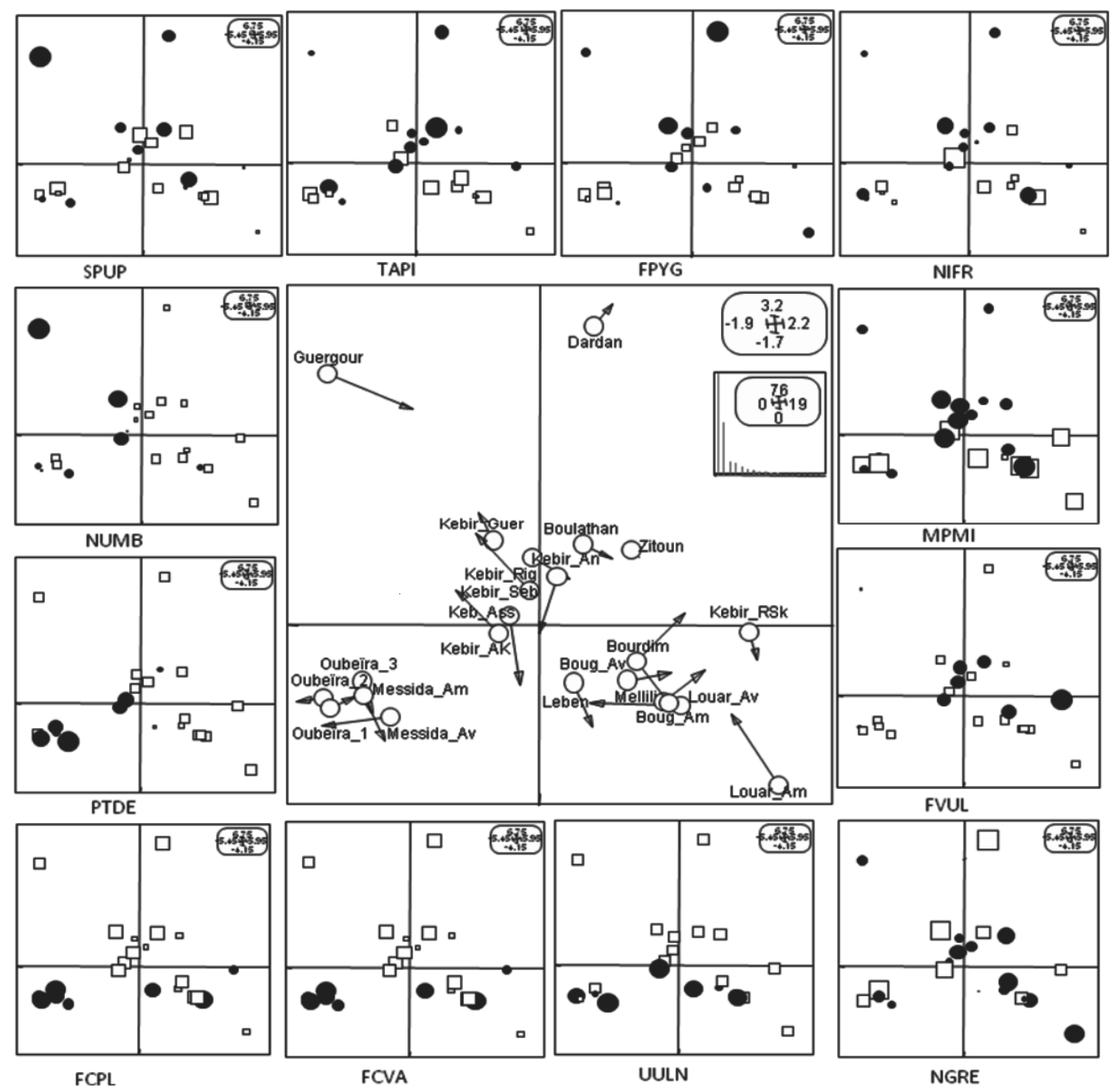

Fig. 2. F1xF2 factorial plane of CIA with arrows linking stations according to physico-chemical variables (base of arrows) and diatom species (end of arrows). Surrounding the central plot are projections of selected diatoms plotted on the same factorial map with abundance proportional to the area of circles (positive values) or squares (negative values). Eigenvalues are displayed on the inset.

Tab. 2. Summary of the Co-Inertia Analysis for wadi Kebir-East. (Covaria: covariance of the two sets of coordinates projected on to Co-Inertia axes. Varian1: inertia of the environmental table projected on to CoInertia axes. Varian2: inertia of the diatoms table projected on to Co-Inertia axes. Correla.: correlation between the two new sets of coordinates resulting from the CIA. INER1: maximal projected inertia of the environmental table. INER2: maximal projected inertia of the diatoms table).

\begin{tabular}{ccccccc}
\hline Num. & Covaria & Varian1 & Varian2 & Correla. & INER1 & INER2 \\
\hline 1 & 8.662 & 7.577 & 10.970 & 0.950 & 7.762 & 13.400 \\
2 & 6.215 & 4.248 & 10.360 & 0.937 & 4.125 & 12.020 \\
\hline
\end{tabular}

from the CIA was tested by carrying out 10,000 Co-Inertia Analyses of the environmental descriptors and the diatom data sets after random permutations of their rows (Dolédec \& Chessel 2004).

\section{RESULTS}

The results of the CIA between habitat characteristics represented by measured environmental variables, and diatom species of the Kebir-East wadi are presented in figure 2. As shown by Monte Carlo simulations, the co-inertia was statistically highly significant $(p<0.001)$. The first two axes of the CIA accounted for $48.6 \%$ and $25.0 \%$ respectively of the total covariance (Tab. 2).

Every arrow shown in the figure indicates a site with its environmental descriptors (the circled numbers at the base of the arrow) and its species (the end of the arrow). 
Tab. 3. Summary table of chemical and physical environmental variables in wadi KebirEast during the study period $(\mathrm{n}=174)$.

\begin{tabular}{|c|c|c|c|c|c|c|}
\hline & Unit & Mean & SE & Median & Min. & Max. \\
\hline $\mathrm{NO}_{3}{ }^{-}$ & $\mathrm{mg} \mathrm{L}^{-1}$ & 13.3 & 8.4 & 9.8 & 1.1 & 32.4 \\
\hline $\mathrm{NO}_{2}^{-}$ & $\mathrm{mg} \mathrm{L}^{-1}$ & 0.5 & 0.4 & 0.4 & 0.0 & 1.8 \\
\hline $\mathrm{NH}_{4}{ }^{+}$ & $\mathrm{mg} \mathrm{L}^{-1}$ & 0.8 & 0.7 & 0.6 & 0.0 & 3.4 \\
\hline $\mathrm{PO}_{4}{ }^{3-}$ & $\mathrm{mg} \mathrm{L}^{-1}$ & 0.9 & 1.0 & 0.7 & 0.0 & 5.6 \\
\hline Turbidity & FTU & 224.9 & 283.0 & 129.8 & 0.8 & 967.0 \\
\hline Flow velocity & $\mathrm{cm} \mathrm{s}^{-1}$ & 28.0 & 20.3 & 22.6 & 0.3 & 81.4 \\
\hline $\mathrm{O}_{2}$ saturation & $\%$ & 117.5 & 27.6 & 111.0 & 45.3 & 182.0 \\
\hline $\mathrm{O}_{2}$ dissolved & $\mathrm{mg} \mathrm{L}^{-1}$ & 12.8 & 3.4 & 11.7 & 4.2 & 28.5 \\
\hline Temperature & ${ }^{\circ} \mathrm{C}$ & 12.6 & 4.2 & 11.3 & 6.4 & 25.5 \\
\hline $\mathrm{Cl}^{-}$ & $\mathrm{mg} \mathrm{L}^{-1}$ & 153.8 & 87.3 & 127.9 & 46.0 & 586.0 \\
\hline Conductivity & $\mu \mathrm{s} \mathrm{cm}^{-1}$ & 622.0 & 195.5 & 604.5 & 140.0 & 1511.0 \\
\hline Alcalinity (TAC) & $\mathrm{mg} \mathrm{L}^{-1}$ & 117.0 & 76.6 & 92.5 & 5.0 & 367.3 \\
\hline $\mathrm{pH}$ & U & 7.0 & 0.6 & 6.9 & 5.4 & 9.4 \\
\hline $\mathrm{SO}_{4}{ }^{2-}$ & $\mathrm{mg} \mathrm{L}^{-1}$ & 110.2 & 57.6 & 117.0 & 3.2 & 237.0 \\
\hline $\mathrm{Ca}^{2+}$ & $\mathrm{mg} \mathrm{L}^{-1}$ & 86.8 & 44.2 & 76.0 & 17.0 & 235.0 \\
\hline $\mathrm{Mg}^{2+}$ & $\mathrm{mg} \mathrm{L}^{-1}$ & 57.6 & 47.3 & 32.4 & 10.0 & 175.0 \\
\hline Total hardness (TH) & $\mathrm{mg} \mathrm{L}^{-1}$ & 171.2 & 64.4 & 165.0 & 58.0 & 456.0 \\
\hline
\end{tabular}

Tab. 4. Acronyms and full names of the widespread species over the Kebir-East hydrosystem and its tributaries.

\begin{tabular}{|c|c|c|c|}
\hline Acronym & Species & Acronym & Species \\
\hline AAMB & Aulacoseira ambigua (Grunow) Simonsen & NDUB & Nitzschia dubia W.M.Smith \\
\hline $\mathrm{ADM}$ & Achnanthidium minutissimum (Kützing) Czarnecki & NERI & Navicula erifuga Lange-Bertalot \\
\hline AGCU & Aulacoseira granulata (Ehr.) Simonsen morphotype curvata & NFIL & Nitzschia filiformis (W.M.Smith) Van Heurck var. filiformis \\
\hline APED & Amphora pediculus (Kützing) Grunow & NGRE & Navicula gregaria Donkin \\
\hline AUGR & Aulacoseira granulata (Ehr.) Simonsen & NIFR & Nitzschia frustulum (Kützing) Grunow var. frustulum \\
\hline BBRE & Brachysira brebissonii Ross in Hartley ssp. brebissonii & NLAN & Navicula lanceolata (Agardh) Ehrenberg \\
\hline BPAX & Bacillaria paxillifera (O.F. Müller) Hendey var. paxillifera & NPAL & Nitzschia palea (Kützing) W.Smith \\
\hline CAFF & Cymbella affinis Kützing var. affinis & NRAD & Navicula radiosa Kützing \\
\hline CEUG & Cocconeis euglypta Ehrenberg & $\mathrm{NRCH}$ & Navicula reichardtiana Lange-Bertalot var. reichardtiana \\
\hline CMEN & Cyclotella meneghiniana Kützing & NRCS & Navicula recens (Lange-Bertalot) Lange-Bertalot \\
\hline COCE & Cyclotella ocellata Pantocsek & NROS & Navicula rostellata Kützing \\
\hline CPLA & Cocconeis placentula Ehrenberg var. placentula & NRST & Nitzschia rosenstockii Lange-Bertalot \\
\hline CTPU & Ctenophora pulchella (Ralfs ex Kütz.) Williams et Round & NSIG & Nitzschia sigma (Kützing)W.M.Smith \\
\hline DVUL & Diatoma vulgaris Bory & NSYM & Navicula symmetrica Patrick \\
\hline ENMI & Encyonema minutum (Hilse in Rabh.) D.G. Mann & NTRV & Navicula trivialis Lange-Bertalot var. trivialis \\
\hline FCPL & Fragilaria capitellata (Grunow in Van Heurck) J.B. Petersen & NUMB & Nitzschia umbonata (Ehrenberg) Lange-Bertalot \\
\hline FCVA & Fragilaria capucina Desmazieres var. vaucheriae (Kützing) Lange-Ber & NVEN & Navicula veneta Kützing \\
\hline FFAM & Fragilaria famelica (Kützing) Lange-Bertalot var. famelica & PLLE & Plagiotropis lepidoptera (Gregory) Kuntze \\
\hline FPYG & Fallacia pygmaea (Kützing) Stickle \& Mann ssp. pygmaea Lange-Ber & PTDE & Planothidium delicatulum (Kütz.) Round \& Bukhtiyarova \\
\hline FVIR & Fragilaria virescens Ralfs & RABB & Rhoicosphenia abbreviata (C.Agardh) Lange-Bertalot \\
\hline FVUL & Frustulia vulgaris (Thwaites) De Toni & RGIB & Rhopalodia gibba (Ehr.) O.Muller var. gibba \\
\hline GMIN & Gomphonema minutum (Ag.)Agardh f. minutum & RUNI & Reimeria uniseriata Sala Guerrero \& Ferrario \\
\hline GOLI & Gomphonema olivaceum (Hornemann) Brébisson var. olivaceum & SBRE & Surirella brebissonii Krammer \& Lange-Bertalot var. brebissonii \\
\hline GPAR & Gomphonema parvulum (Kützing) Kützing var. parvulum f. parvulum & SBRI & Surirella brightwellii $\mathrm{W}$.Smith var. brightwellii \\
\hline GYAT & Gyrosigma attenuatum (Kützing) Rabenhorst & SPUP & Sellaphora pupula (Kützing) Mereschkowksy \\
\hline LGOE & Luticola goeppertiana (Bleisch in Rabenhorst) D.G. Mann & TAPI & Tryblionella apiculata Gregory \\
\hline MPMI & Mayamaea permitis (Hustedt) Bruder \& Medlin & TLEV & Tryblionella levidensis Wm. Smith \\
\hline MVAR & Melosira varians Agardh & UUAC & Ulnaria ulna (Nitzsch.) Compère var. acus (Kütz.) Lange-Bertalot \\
\hline NCTV & Navicula caterva Hohn \& Hellerman & UUAN & Ulnaria ulna Sippe angustissima (Grunow) Lange-Bertalot \\
\hline NDIS & Nitzschia dissipata (Kützing)Grunow var. dissipata & UULN & Ulnaria ulna (Nitzsch.) Compère \\
\hline
\end{tabular}

Measured values (mean, median, minimum and maximum) for the physical and chemical variables $(n=174)$ in the Kebir-East wadi are presented in table 3. A list of the acronyms of the names of the species used in figure 2 are given in table 4.

From 182 samples collected during the period from 2005 to 2008,322 species were identified. Among the recorded taxa, 100 are considered as frequent $(>25 \%)$ over the whole length of wadi Kebir-East and its tributaries (Tab. 4). Most are cosmopolites as Achnantidium minutissimum (ADMI), Amphora pediculus (APED), Cymbella affinis (CAFF), Cyclotella ocellata (COCE), Encyonema caespitosum (ECAE), Achnanthidium exiguum ((ADEG), Amphora oligotraphenta (AOLG),
Encyonopsis subminuta (ESUM), and Gomphonema acuminatum (GACU) (Fig. 3).

CIA highlighted the links between the physicochemical characteristics of the wadi and the various diatoms species. The results presented in figure 2 show the mean values of physico-chemical variables for each studied site (Tab. 3), and the widespread species across the 23 sampled sites ( $i \geq 3$ sites).

Axis 1 separated upstream from downstream zones of the Kebir hydrosystem: the upstream zone, well oxygenated, was characterized with high flow velocity, and strong mineralization of waters which entailed the presence of species like Cyclotella ocellata (COCE), Navicula gregaria (NGRE), Frustulia vulgaris (FVUL) and 


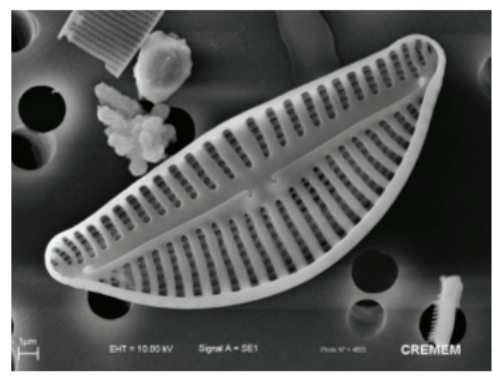

Encyonema caespitosum

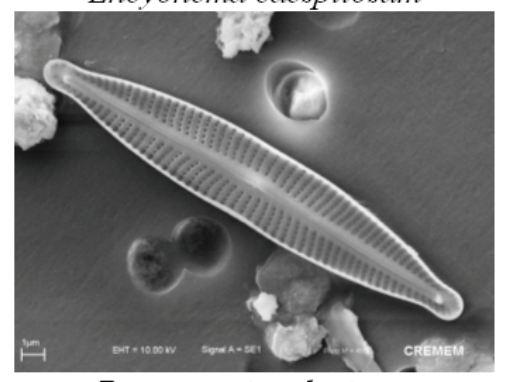

Encyonopsis submimuta

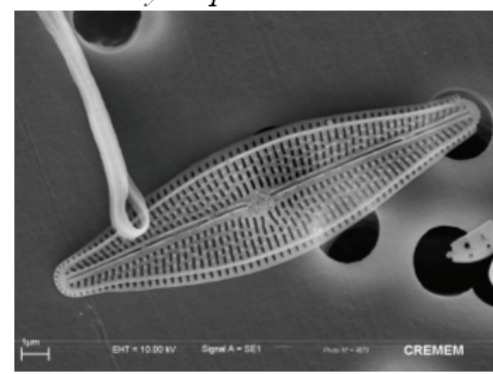

Brachysira brebissonii

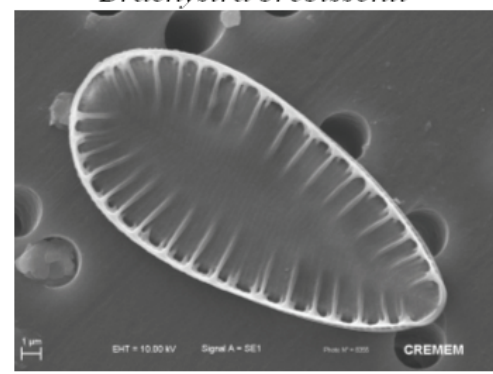

Surirella brebissonii

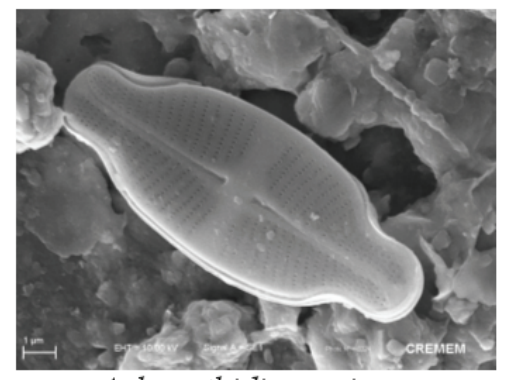

Achnanthidium exigum

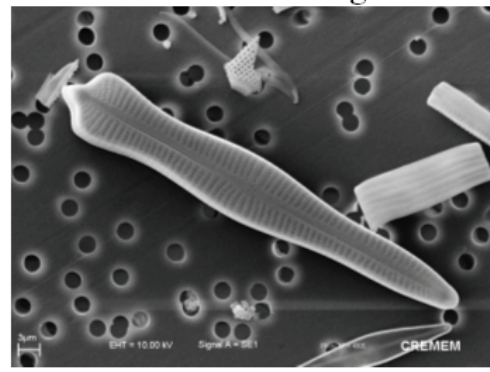

Gomphonema acuminatum

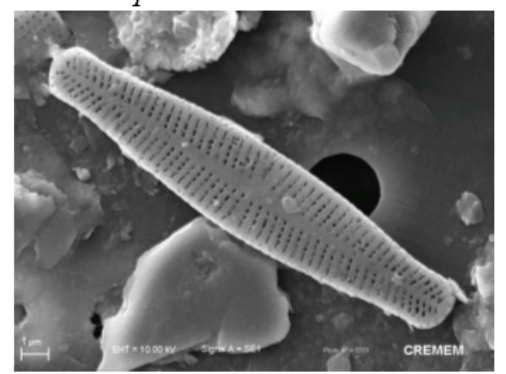

Achnanthidium mimutissimum

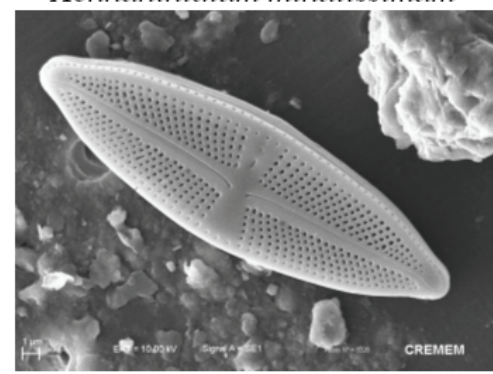

Luticola goeppertiana

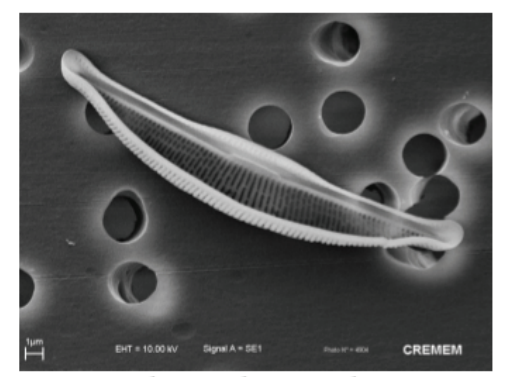

Amphora oligotraphenta

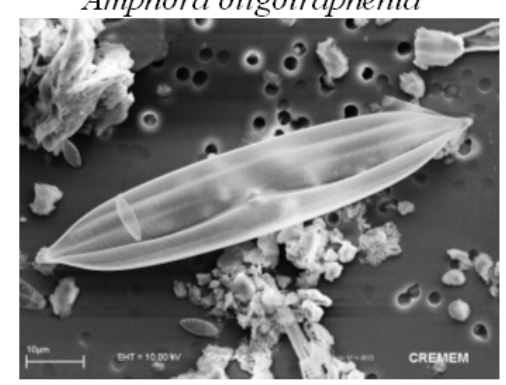

Plagiotropis lepidoptera

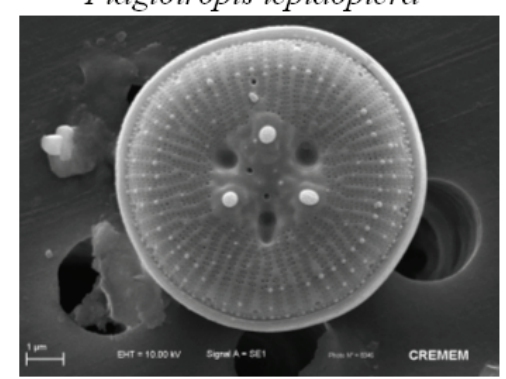

Cyclotella ocellata

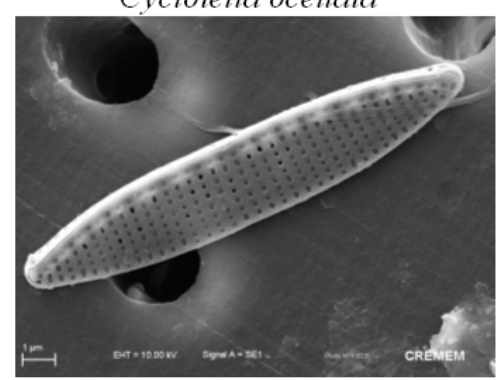

Nitzschia frustulum

Fig. 3. Photos of mounted diatom frustules taken with MEB.

Plagiotropis lepidoptera (PLLE). The site Bourdim (site 17) exhibited some floral particularities, such as the simultaneous presence of Fragilaria pulchella and Brachysira brebissonii (BBRE) (Fig. 3).

The sites Zitoun (site 18) and Kebir at R' Mel Souk (site 3) (average water conductivity $>700 \mu \mathrm{S} \mathrm{cm}^{-1}$ ) were found to house robust forms of Reimeria uniseriata (RUNI) with exceptionally strong stria.

Axis 2 of the CIA, displayed distinct differences in water chemistry and diatom community types among downstream sites.

- The downstream reaches (sites 20-23) were characterized by strong water conductivity and chloride concentration and were occupied by species like
Nitzschia frustulum (NIFR) and Tryblionella apiculata (TAPI). Wadis Guergour and Dardan, presented weak current flows, drying up in autumn, and were also similarly associated with salinity (water conductivity $\left(1200 \mu \mathrm{S} \mathrm{cm}^{-1}\right)$ and chloride concentration (400 $\mathrm{mg} \mathrm{L}^{-1}$ ). These sites were also characterized by the presence of species of anthropogenic ecosystems such as: Fallacia pygmaea (FPYG), Mayamaea permittis (MPMI) and Sellaphora pupula (SPUP).

- The sites located in close proximity to Lake Oubeïra (sites 9-13) (Fig. 1) were associated with low water conductivity, finer substrata (sand, silt) and strong concentrations of $\mathrm{NO}_{3}^{-}, \mathrm{NH}_{4}^{+}, \mathrm{NO}_{2}^{-}, \mathrm{PO}_{4}{ }^{3-}$ (Tab. 3). Local episodes of water pollution were associated 
with a transient shift towards the dominance of Fragilaria capitellata (FCPL) and Synedra ulna (UULN). These sites were also colonized by prostrate diatoms, including several species of Navicula (NVEN, NTRV, NRCS) and Nitzschia (NUMB, NPAL). In the Messida wadi, an epilithic diatom community was found associated with low water conductivity and gravel substrata, consisting of Achnanthes (ADMI, AGCU) as well as stalked taxa like Gomphonema minutum (GMIN).

\section{DISCUSSION}

The distribution of diatom species along environmental gradients has been the focus of numerous studies which have been used to infer processes that determines the structure of communities (Dunson \& Travis 1991; Wellborn et al. 1996; McPeek \& Brown 2000). This is true for lotic systems which have witnessed in the last decades a strong theoretical framework providing guidance in the study of running waters (Townsend \& Hildrew 1994). The concept of environmental filters in rivers (Poff 1997), an extension of Southwood's River Habitat Templet (1977), suggests that life history traits strategies are shaped by habitat and disturbance, thus generating predictions to be tested (Townsend \& Hildrew 1994; Statzner et al. 2004). It is, however, unclear how widespread such patterns are and how broadly these hypotheses apply. As diatom assemblages are thought to be driven by local environmental factors rather than regional processes (Soininen 2004), it may be useful therefore to describe such patterns and identify environmental drivers of species assemblages in different geographical settings, especially in arid regions like North Africa. Mediterranean rivers, especially southern ones, are subjected to a wide spectrum of natural fluctuations and anthropogenic disturbances driven by a seasonal sequence of extreme flooding and drying (Gasith \& Resh 1999).

The present study represents the first attempt on typology of benthic diatom assemblages and characterization of their ecological responses to environmental gradients in an Algerian hydrosystem, the Kebir-East wadi. Although the knowledge of Algerian wadi has increased in recent years (Arab et al. 2004; Moubayed et al. 2007), little attention has previously been given to diatoms. In the present study 322 benthic diatom species were recorded and the majority were cosmopolitan taxa. Because of their small size, diatom assemblages are thought to be dominated by cosmopolitan species (Lange-Bartelot 2000) and this view, despite some criticisms (Kociolek \& Spaulding 2000), has been upheld (Bate et al. 2004). In line with previous studies in other geographical settings (Potapova \& Charles 2002), the CIA revealed a strong longitudinal gradient with upstream sites characterized by high water velocity and dissolved oxygen contrasting with downstream sites characterized by turbid water and affected by a higher level of organic pollution. The ecological impact of Pand N-loading from agricultural activities is most apparent around Lake Oubeïra with a distinct diatom community [Fragilaria capucina (FCVA), Planothidium delicatulum (PTDE), Achnanthidium minutissimum (ADMI) and Luticola goeppertiana (LGOE)]. Environmental stressors like livestock grazing and intensive agricultural activities are known to increase nutrient runoff, resulting in downstream eutrophication (Jüttner et al. 1996; Brown \& May 2000). Diatoms assemblages of the Kebir-East wadi seem also to be most sensitive to conductivity, a variable known to reflect the dominant geological nature of the watershed (Leland \& Porter 2000; Rimet et al. 2007) and to influence diatom communities (Biggs 1990; Pan et al. 1999; Soininen 2004). The downstream sites may also have been influenced by sea intrusions which may be responsible for the higher water salinity.

The present work also represents a first step of attempting to gain a better understanding of the composition and distribution of benthic diatoms in northeastern Algerian rivers. The next step will be to investigate whether similar patterns are found across the varied North African landscapes. The diatom-based water quality indicators of the ecological status of hydrosystems should be developed by testing the applicability of European Indices such as the Diatom Biological Index (Prygiel \& Coste 2000) on North African wadi or by adapting such indices to take into account ecological attributes of native taxa.

\section{CONCLUSIONS}

The combined effects of demography and climate change will only exacerbate the increasing pressure on precious water resources in North Africa. One way to address threats such as pollution is to implement a management strategy with improved monitoring schemes of freshwater habitats. As a prelude to develop diatombased water quality indicators of the ecological status of hydrosystems, there is a need to improve the knowledge of ecological determinants of diatom assemblages in North Africa. Results show that diatom species composition of wadi Kebir-East is influenced by geological, chemical, physical and anthropogenic factors like agricultural activities and livestock grazing.

\section{ACKNOWLEDGEMENTS}

We are most grateful to two anonymous referees for their valuable comments which greatly improved the manuscript. We wish to thank M. Coste and J. Roseberry, Unité de Recherche REQUE, Cemagref groupement de Bordeaux (France), for their help in identifying diatom species (all the diatom species photos under MEB were taken by Michel Coste). This research was funded in part by the Algerian Ministère de l'Enseignement Supérieur et de la Recherche Scienti- 
fique (MESRS) and DSFP, King Saud University, Saudi Arabia.

\section{REFERENCES}

AFNOR. 2000. Norme Française NFT90-354. Détermination de l'Indice Biologique Diatomées (IBD), June 2000: 1-63.

Arab, A., S. Lek, A. Lounaci \& Y.S. Park. 2004. Spatial and temporal patterns of benthic invertebrate communities in an intermittent river (North Africa). Ann. Limnol. - Int. J. Lim., 40: 317-327.

Bate, G., P. Smailes \& J. Adams. 2004. A water quality index for use with diatoms in the assessment of rivers. Water $S A$, 30: 493-498.

Baudrimont, R. 1973. Précisions sur l'écologie en Algérie, de Terpsinoe musica Her. (Bacillariophycées Anaulacées). Bull. Soc. Linn. Bordeaux, 3: 21-24.

Belaidi, N., A. Taleb \& J. Gagneur. 2004. Composition and dynamics of hyporheic and surface fauna in a semi-arid stream in relation to the management of a polluted reservoir. Ann. Limnol. - Int. J. Lim., 40: 237-248.

Biggs, B.J.F. 1990. Periphyton communities and their environmental gradients in New Zealand rivers. N.Z. J. Mar. Freshwat. Res., 24: 367-386.

Brown, L.R. \& J.T. May. 2000. Macroinvertebrate assemblages on woody debris and their relations with environmental variables in the Lower Sacramento and San Joaquim River drainages, California. Environ. Monit. Assess., 64: 311-329.

Coste, M., C. Bosca, C. \& A. Dauta. 1991. Use of algae for monitoring rivers in France. In: B.A. Whitton, E. Rott \& G. Fridriech (Eds), Use of Algae for monitoring rivers. Institut für Botanik, Universität Innsbruck: 75-83.

Dolédec, S. \& D. Chessel. 1994. Co-inertia analysis: an alternative method for studying species-environment relationships. Freshwat. Biol., 31: 277-294.

Dunson, W.A. \& J. Travis. 1991: The role of abiotic factors in community organization. Am. Nat., 138: 1067-1091.

European Commission, 2000. Directive 2000/60/EC of $23^{\text {rd }}$ October 2000 establishing a framework for community action in the field of water policy. O.J., 327: 1-72.

Gasith, A. \& V.H. Resh. 1999. Streams in Mediterranean climate regions: abiotic influences and biotic responses to predictable seasonal events. Annu. Rev. Ecol. Syst., 30: 5181.

Germain, H. 1981. Flore des Diatomées. Diatomophycées eaux douces et saumâtres du Massif Armoricain et des contrées voisines d'Europe occidentale. Boubée, Paris.

Hartley, B., H.G. Barber, J.R. Carter \& P.A. Sims, 1996. An atlas of British Diatoms. Biopress Limited, Bristol.

Hulme, M., R. Doherty, T. Ngara, M. New \& D. Lister. 2001. African climate change: 1900- 2100. Clim. Res., 17: 145168.

Hynes, H.B.N. 1970. The ecology of running waters. Univ. Toronto Press, Toronto.

Johansson, C. 1982. Attached algal vegetation in running waters of Jämtland, Sweden. Acta Phytogeographica Suecica, 71: 1-84.

Junk, W.J. 1999. The flood pulse concept of large rivers: Learning from the tropics. Arch. Hydrobiol., 115: 261280.

Jüttner, I., S. Sharma, B.M. Dahal, S.J. Ormerod, P.J. Chinonides \& E.J. Cox. 1996. Diatoms as indicators of stream quality in the Katmandu Valley and Middle Hills of Nepal and India. Freshwat. Biol., 48: 2065-2084.

Kelly, M.G. 2000. Identification of Common Benthic Diatoms in Rivers. Field Studies, 9: 583-700.

Kelly, M.G. \& B.A. Whitton. 1995. The trophic diatom index: a new index for monitoring eutrophication in rivers. $J$. Appl. Phycol., 7: 433-444.
Kociolek, J.P. \& A.A. Spaulding. 2000. Freshwater diatom biogeography. Nova Hedw., 71: 223-241.

Kovacs, C., M. Kahlert \& J. Padisak. 2006. Benthic diatom communities along $\mathrm{pH}$ and $\mathrm{TP}$ gradients in Hungarian and Swedish streams. J. Appl. Phy., 18: 105-117.

Krammer, K. \& H. Lange-Bertalot. 1986-1991. Bacillariophyceae. 1-4. Süsswasserflora von Mitteleuropa. Gustav Fisher Verlag, Stuttgart.

Lange- Bertalot, H. 2000: Icon. Diatom. 7 Koeltz Scientific Books, Koenigstein.

Leland, H. \& S. Porter. 2000. Distribution of benthic algal in the upper Illinois River basin in relation to geology and land use. Freshwat. Biol., 44: 279-301.

Lounaci, A., S. Brosse, A. Thomas \& S. Lek. 2000. Abundance, diversity and community structure of macroinvertebrates in an Algerian stream: the Sébaou wadi. Ann. Limnol.- Int. J. Lim., 36: 123-133.

McPeek, M.A. \& J.M. Brown. 2000. Building a regional species pool: Diversification of the Enallagma damselflies in eastern North American waters. Ecology, 81: 904-920.

Moubayed, J., A. Lounaci \& D. Lounaci-Daoudi. 2007. Nonbiting midges from Algeria, North Africa (Diptera, Chironomidae). Ephemera, 8: 93-99.

Pan, Y., R.J. Stevenson, B.H. Hill \& A.T. Herlihy. 2000: Ecoregions and benthic diatom assemblages in Mid-Atlantic Highlands streams, USA. J. North Am. Benthol. Soc., 19: 518-540.

Pan, Y., R.J. Stevenson, B. Hill, P.R. Kaufman \& A.T. Herlihy. 1999. Spatial patterns and ecological determinants of benthic algal assemblages in Mid-Atlantic Highland streams. J. Phycol., 35: 460-468.

Patrick, R. \& C.W. Reimer. 1966. The Diatoms of the United States. Vol. 1. Acad. Nat. Sci. Phil. Monogr., 13: 1-699.

Patrick, R. \& C.W. Reimer. 1975. The Diatoms of the United States. Vol. 2, Part 1. Acad. Nat. Sci. Phil. Monogr., 13: 1213.

Pipp, E. \& E. Rott. 1994. Classification of running-water sites in Austria based on benthic algal community structure. Verh. Internat. Verein. Limnol., 25: 1610-1613.

Poff, N.L. 1997. Landscape filters and species traits: towards mechanistic understanding and prediction in stream ecology. J. N. Am. Benthol. Soc., 16: 391-409.

Potapova, M. \& D.F. Charles. 2002. Benthic diatoms in USA rivers: distributions along spatial and environmental gradients. J. Biogeogr., 29: 167-187.

Potapova, M. \& D.F. Charles. 2003. Distribution of benthic diatoms in US rivers in relation to conductivity and ionic composition. Freshwat. Biol., 48: 1311-1328.

Prygiel, M. \& M. Coste. 2000. Guide méthodologique pour la mise en ouvre de l'Indice Biologique Diatomées NFT90354. Agences de l'Eau, MATE, Cemagref Bordeaux .

Reavie, E.D. \& J.P. Smol. 1998. Epilithic diatoms of the St. Lawrence River and their relationships to water quality. Can. J. Bot., 76: 251-257.

Rimet, F., J. Gomà, J. Cambra, E. Bertuzzi, M. Cantonati, C. Cappelletti, F. Ciutti, A. Cordonier, M. Coste, F. Delmas, J. Tison, L. Tudesque, H. Vidal \& L. Ector. 2007. Benthic diatoms in western European streams with altitudes above $800 \mathrm{~m}$ : Characterisation of the main assemblages and correspondence with ecoregions. Diatom Res., 22: 147-188.

Rott, E., H. Duthie \& E. Pipp. 1998. Monitoring organic pollution and eutrophication in the Grand River, Ontario, by means of diatoms. Can. J. Fish. Aquat. Sci., 55: 14431453.

Samraoui, B. \& G. de Bélair. 1998. Les zones humides de la Numidie orientale. Bilan des connaissances et perspectives de gestion. Synthèse, (Numéro Spécial) 4: 1-90.

Schoeman, F.R. 1979. Diatoms as indicators of water quality in the upper Hennops river. J. Limnol. Soc. South. Afr., 5: 73-78. 
Soininen, J. 2002. Responses of epilithic diatom communities to environmental gradients in some Finnish rivers. Int. Rev. Hydrobiol., 87: 11-24.

Soininen, J. 2004. Determinants of benthic diatom community structure in Boreal streams: the role of environmental and spatial factors at different scales. Internat. Rev. Hydrobiol., 89: 139-150.

Southwood, T.R.E. 1977. Habitat, the templet for ecological strategies? J. Anim. Ecol., 46: 337-365.

Stanford, J.A. \& J.V. Ward. 1988. The hyporheic habitat of river ecosystems. Nature, 335: 64-66.

Statzner, B., S. Doledec \& B. Hugueny. 2004. Biological trait composition of European streams invertebrate communities: assessing the effects of various trait filter types. Ecography, 27: 470-488.

Thioulouse, J., M. Simier \& D. Chessel. 2004. Simultaneous analysis of a sequence of paired ecological tables. Ecology, 85: 272-283.

Received: August 2010

Accepted: November 2010
Townsend, C.R. \& A.G. Hildrew. 1994. Species traits in relation to a habitat template for river systems. Freshwat. Biol., 31: 357-375.

Zouini, D. 1997. Ressources en eau de surface pour l'aménagement hydraulique dans le bassin de l'Oued El Kebir (Nord-est algérien). Sécheresse, 8: 9-13.

Van Dam, H., A. Mertens \& J. Sinkeldam. 1994. A coded check-list and ecological indicator values of freshwater diatoms from the Netherlands. Neth. J. Aquat. Ecol., 28: 117-133.

Vannote, R.L., G.W. Minshall, K.W. Cummins, J.R. Sedell \& C.E. Cushing. 1980. The river continuum concept. Can. Bull. Fish. Aquat. Sci., 37: 130-137.

Wellborn, G.A., D.K. Skelly \& E.E. Werner. 1996. Mechanisms creating community structure across a freshwater habitat gradient. Annu. Rev. Ecol. Syst., 27: 337-363.

Whitton, B.A. \& M.G. Kelly. 1995. Use of algae and other plants for monitoring rivers. Aust. J. Ecol., 20: 45-56. 